\title{
Textile industry and occupational cancer
}

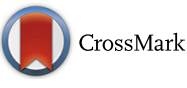

\author{
Zorawar Singh $^{1 *}$ and Pooja Chadha ${ }^{2}$
}

\begin{abstract}
Background and summary: Thousands of workers are engaged in textile industry worldwide. Textile industry involves the use of different kinds of dyes which are known to possess carcinogenic properties. Solvents used in these industries are also associated with different health related hazards including cancer. In previous studies on textile and iron industries, the authors have reported genotoxicity among them and observed occurrence of cancer deaths among textile industry workers. Thus, an attempt has been made to compile the studies on the prevalence of different types of cancers among textile industry workers.

Literature search: A wide literature search has been done for compiling the present paper. Papers on cancer occurrence among textile industry workers have been taken from 1976 to 2015. A variety of textile dyes and solvents, many of them being carcinogenic, are being used worldwide in the textile industry. The textile industry workers are therefore, in continuous exposure to these dyes, solvents, fibre dusts and various other toxic chemicals. The present study evaluates the potential of different chemicals and physical factors to be carcinogenic agents among occupationally exposed workers by going through various available reports and researches. Papers were collected using different databases and a number of studies report the association of textile industry and different types of cancer including lung, bladder, colorectal and breast cancer. After going through the available reports, it can be concluded that workers under varied job categories in textile industries are at a higher risk of developing cancer as various chemicals used in the textile industry are toxic and can act as potential health risk in inducing cancer among them. Assessing the cancer risk at different job levels in textile industries may be found useful in assessing the overall risk to the workers and formulating the future cancer preventive strategies.
\end{abstract}

Keywords: Textile industries, Cancer, Occupational cancer, Mutagenic, Mortality

Abbreviations: BTC, Biliary Tract Cancer; HR, Hazard Ratio; IRR, Incident Rate Ratios; MFs, Magnetic Fields; OR, Odds Ratio; PRR, Proportional Registration Ratios; SIR, Standardized Incidence Ratios; SMRs, Standardized Mortality Ratios

\section{Background}

Textile is one of the leading industries in the world. The textile industry workers are exposed to a number of chemicals including dyes, solvents, optical brighteners, finishing agents and numerous types of natural and synthetic fibre dusts which affect their health. Various dyes and solvents used by the textile industry have been found to have mutagenic and carcinogenic properties. Workers engaged in finishing processes are frequently exposed to crease-resistance agents. These agents may release formaldehyde which is known for its toxicity. Workers are also exposed to flame retardants including organophosphorus and organobromine compounds. The

\footnotetext{
* Correspondence: zorawarsinghs@rediffmail.com

'Department of Zoology, Khalsa College, G.T. Road, Amritsar, Punjab 143001, India

Full list of author information is available at the end of the article
}

textile industries use different kinds of dyes including the most commonly used azo dyes which are aromatic hydrocarbon derivatives of benzene, toluene, naphthalene, phenol and aniline. The solvents used by the workers in different sections result in a major carcinogenic effect by direct contact with the subjects. A number of studies have been put forward emphasizing the occurrence of different types of cancers among textile industry workers [1-34]. Keeping in view the importance of the issue, a brief review of the same is presented herewith.

\section{Bladder cancer}

Different studies have pointed out the occurrence of bladder cancer among textile industry workers [35-37]. Gonzales et al. [35] presented results from a casecontrol study carried out in the county of Mataro, Spain. 
The study was based on 57 cases that were hospitalized for or died from bladder cancer between 1978 and 1981. An increased risk for past employment in the textile industry (Odds ratio, $\mathrm{OR}=2.2 ; p=0.038$ ) was found among a group of common occupational sectors. Further analyses in the study indicated that the risk for subjects who worked in dyeing or printing sectors and who were exposed to azo-dyes was particularly elevated $(\mathrm{OR}=4.41$; $95 \%$ confidence limits; 1.15-16.84). Similarly, Zheng et al. [36] conducted a study on 1,219 incident bladder cancer cases based on gender which were diagnosed during the period 1980 to 1984 . The bladder cancer cases were compared with 1982 census data on employment. Standardized incidence ratios (SIR) for bladder cancer were estimated for occupation and industry classifications and significant excess risks were observed for dyers, textile bleachers, and finishers (male: SIR $=169$ ); metal refining and processing workers (male: SIR = 139; female: SIR = 197); apparel industry workers and workers engaged in other textile products manufacturing (female: SIR =204). Serra et al. [37] also investigated the risk of bladder cancer in Spanish textile workers and analyzed the data from a multicenter hospital-based case-control study in Spain. The data included 1219 bladder cancer cases and 1271 controls. Out of those cases, 126 cases and 122 controls reported a history of previous employment in the textile industry. Increased risks were observed for weavers and workers engaged in winding, warping and sizing. Higher risk was also found for workers who were exposed to synthetic materials. Table 1 shows the incidence of different types of cancers among textile industry workers.

\section{Lung cancer}

A number of studies report the association of textile industry and lung cancer. The association between endotoxin exposure and lung cancer risk was found in a cohort of female textile workers [23]. Bacterial endotoxin which is a contaminant of raw cotton fibre and cotton dust, has been proposed as a protective agent against cancer. The action of endotoxin may be through the innate and acquired immune systems. Long-term and high-level exposure to endotoxin, compared with no exposure was found to be associated with a reduced risk of lung cancer in this cohort. Similarly, Checkoway et al. [38] investigated the associations of various exposures like wool, synthetic fibre dusts, formaldehyde, silica, dyes and metals with lung cancer in the textile industry. But in this study, no associations were observed for lung cancer with wool, silk, synthetic fibre dust or with other agents. Agalliu et al. [39] investigated the associations between contiguous windows of endotoxin exposure and risk of lung cancer, and reported that endotoxin is consistently associated with a reduced risk of lung cancer. Data from 602 cases of female textile workers was evaluated in Shanghai, China and an inverse risk trend of lung cancer with increasing levels of endotoxin exposure was found. In a study of Italian textile workers $(N=1966)$, on the basis of 68 deaths from mesothelioma, the standardized mortality ratio (SMR) was found to be 6627 for workers employed only under the age of 30 years. SMR was found to be 8019 for workers those were employed both under the age of 30 years and at the age of 30-39 years. SMR was 5891 for those employed both under the age of 30 years and at the age of 40 years or more. The results of the study also indicated that stopping the exposure of the workers does not modify the subsequent mesotheliomas risk [40].

Elliott et al. [41] conducted a study in North and South Carolina on two US cohorts of asbestos textile workers exposed to chrysotile. The study found an increasing risk of lung cancer mortality with cumulative fibre exposure. Similarly, Wang et al. [42] determined the mortality associated with exposure to chrysotile asbestos from a textile factory in China. The study was done from 1972 to 2008 and a total 577 workers were followed. Follow-up rate for the study was $98.5 \%$ over 37 years. The follow-up of the workers generated a data of 17,508 persons including 259 deaths (from all causes), 2 mesotheliomas and 53 lung cancers. The highest cancer mortality was observed in the high exposure group, with 1.5-fold age-adjusted mortality from all cancers and 2-fold from lung cancer when compared to the low exposure group. Both smokers and non-smokers at the high exposure level had a high death risk from lung cancer. A clear exposure-response trend was seen in smokers which confirmed an increased mortality from lung cancer and all cancers in asbestos workers and the cancer mortality was found to be associated with exposure levels. Deng et al. [43] described mortality in workers exposed to chrysotile asbestos and determined exposure-response relationships between asbestos exposure and mortality from lung cancer. A cohort of 586 workers in an asbestos textile factory was followed. Individual cumulative asbestos exposure was estimated as the product of fibre concentrations and duration of employment in each job and expressed as fibre-years $/ \mathrm{ml}$ (e.g., 30 fibre-years $/ \mathrm{ml}$ is an exposure equivalent to 30 years of exposure at 1 fibre/ml concentration or 15 years at 2 fibres $/ \mathrm{ml}$; and so on). It was found that out of the 226 deaths, 51 deaths were from lung cancer and 37 from asbestosis. A significant exposure-response relationship between asbestosis and lung cancer $(p<0.001)$ was observed. Applebaum et al. [44] also examined the relationship between endotoxin and lung cancer in a study of Chinese female textile workers. Enrollment of the workers was done between 1989 and 1991 and the workers were followed till 1998. In the study, 3038 subcohort members and 602 incident lung cancer cases 
Table 1 Studies based on occurrence of different types of cancers among textile industry workers

Sr. Study Subjects Type of cancer studied Output of the study

No.

1 Serra et al., 2008 [37] Textile industry workers Bladder cancer

$2 \quad$ Li et al., 2015 [33]

Female textile workers

Breast cancer

3 Li et al., 2013 [48]

Female textile workers

Breast cancer

4 Ray et al., 2007 [25]

Female textile workers

Breast cancer

$5 \quad$ Fang et al., 2013 [46]

Textile workers

Cancer mortality

6 Wang et al., 2012 [42]

Asbestos textile workers

Cancer mortality

$7 \quad$ Kuzmickiene and Stukonis, 2010 [49]

Female flax textile workers

Oral cavity and pharynx cancer

8 Gunay and Beser, 2011 [50]

Turkish textile workers

Early breast cancer

$9 \quad$ Kwon et al., 2015 [32]

Female textile workers

Lung cancer

10 Checkoway et al., 2015 [51]

Female textile workers

Lung cancer

11 Rylander and Jacobs, 2015 [34] Female textile workers

Lung cancer

12 Checkoway et al., 2014 [30]

Female textile workers

Lung cancer

13 Wang et al., 2014 [31]

14 Applebaum et al., 2013 [44]

Textile and mining workers

Female textile workers

Lung cancer

15 Gallagher et al., 2013 [52]

Female textile workers

Lung cancer

16 Agalliu et al., 2011 [39]
Female textile workers

Lung cancer
Increased cancer risks were observed for weavers and for workers in winding, warping and sizing. Job more than 10 years appeared to be associated with an increased risk for weavers.

No positive association between night shift work and breast cancer.

No association was observed between cumulative exposure to MFs and overall risk of breast cancer.

Endotoxin or other components of cotton dust exposures may be associated with reduced risks for breast cancer

Mortality risk from gastrointestinal cancers and all cancers combined, with the exclusion of lung cancer, were increased in cotton workers as compared to silk workers.

Highest cancer mortality was observed in the high exposure group, with 1.5-fold age-adjusted mortality from all cancers and 2-fold from lung cancer compared to the low exposure group.

Risk of oral cavity and pharynx cancer was significantly increased in spinning-weaving unit workers with $<10$ years of employment (SIR $5.71,95 \% \mathrm{Cl} 1.56$ to 14.60 ).

$91.6 \%$ of the women working in a textile factory in Turkey had no education about breast cancer.

No increased risk of lung cancer among rotating shift workers.

Reply to [34]: Exposure-response association may change over time owing to complex, yet poorly understood, underlying mechanisms. Endotoxin is a highly variable exposure, and as we noted in the paper, some exposure misclassification was inevitable.

In comment to [30]: The result should be "no relation between endotoxin exposure and lung cancer risk could be detected"

The study did not support a protective effect of endotoxin, but is suggestive of possible lung cancer promotion with increasing time since first exposure.

A clear exposure-response relationship between lung cancer mortality and exposure levels.

A reduced cancer risk in workers exposed to endotoxin, hired $>35$ years before enrolment [IRR $=0.74,95 \% \mathrm{Cl}(0.51$ to 1.07$)]$ as compared to hired $</=35$ years.

Cancer risk was higher in women with a surgical menopause ( $\mathrm{HR}=1.64,95 \% \mathrm{Cl}$ 0.96-2.79) than in those with a natural menopause $(H R=1.35$, $95 \% \mathrm{Cl} 0.84-2.18$ ) demonstrating biological role of hormones in lung carcinogenesis.

Endotoxin exposure that occurred 20 years or more before risk confers the strongest protection against lung cancer, indicating a possible early anti-carcinogenic effect. 
Table 1 Studies based on occurrence of different types of cancers among textile industry workers (Continued)

\begin{tabular}{|c|c|c|c|c|}
\hline 17 & Checkoway et al., 2011 [38] & Female textile workers & Lung Cancer & $\begin{array}{l}\text { No associations were observed for lung cancer } \\
\text { with wool, silk or synthetic fibre dusts. Increased } \\
\text { risks were noted for }>/=10 \text { year exposures to } \\
\text { silica (adjusted HR 3.5, } 95 \% \mathrm{Cl} 1.0 \text { to 13) } \\
\text { and }>\text { /= } 10 \text { year exposures to formaldehyde } \\
\text { (adjusted HR 2.1, } 95 \% \mathrm{Cl} 0.4 \text { to } 11 \text { ). }\end{array}$ \\
\hline 18 & Astrakianakis et al., 2010 [53] & Female textile workers & Lung Cancer & $\begin{array}{l}\text { A dose-related inverse lung cancer risk was } \\
\text { associated with cumulative endotoxin exposure } \\
\text { but a possible anti-carcinogenic effect at early } \\
\text { stages of lung cancer pathogenesis was } \\
\text { not evident. }\end{array}$ \\
\hline 19 & Lenters et al., 2010 [29] & $\begin{array}{l}\text { Agriculture industry and } \\
\text { cotton textile workers }\end{array}$ & Lung Cancer & $\begin{array}{l}\text { Occupational exposure to endotoxin in cotton } \\
\text { textile production and agriculture is protective } \\
\text { against lung cancer }\end{array}$ \\
\hline 20 & Loomis et al., 2009 [28] & Asbestos textile workers & Lung Cancer & $\begin{array}{l}\text { Mortality from all causes, all cancers and lung } \\
\text { cancer was significant higher than expected, } \\
\text { with SMRs of } 1.47 \text { for all causes, } 1.41 \text { for all } \\
\text { cancer and } 1.96 \text { (95\% Cl } 1.73 \text { to 2.20) for } \\
\text { lung cancer. }\end{array}$ \\
\hline 21 & $\begin{array}{l}\text { Kuzmickiene and Stukonis, } \\
2007 \text { [24] }\end{array}$ & Textile workers & Lung Cancer & $\begin{array}{l}\text { Exposure to cotton textile dust at workplaces } \\
\text { for male is associated with adverse lung cancer } \\
\text { risk effects but lung cancer risk decreased with } \\
\text { level of exposure to textile dust. }\end{array}$ \\
\hline 22 & Loomis et al., 2012 [54] & Asbestos textile workers & Lung Cancer & $\begin{array}{l}\text { Lung cancer is associated most strongly with } \\
\text { exposure to long thin asbestos fibres. Fibres } \\
5-10 \mu \mathrm{m} \text { long and }<0.25 \mu \mathrm{m} \text { in diameter } \\
\text { were associated most strongly with lung } \\
\text { cancer mortality. }\end{array}$ \\
\hline 23 & Elliott et al., 2012 [41] & Asbestos textile workers & Lung Cancer & $\begin{array}{l}\text { Increased rates of lung cancer were significantly } \\
\text { found to be associated with overall cumulative } \\
\text { fibre exposure. }\end{array}$ \\
\hline 25 & Wernli et al., 2008b [55] & Textile workers & Ovarian cancer & $\begin{array}{l}\text { An increasing risk of ovarian cancer associated } \\
\text { with cumulative exposure to silica dust (for }<10 \\
\text { years exposure, } \mathrm{HR}=6.8[\mathrm{Cl}=0.6-76] \text {; for }> \\
\text { or }=10 \text { years, } 5.6[1.3-23.6] \text { ). }\end{array}$ \\
\hline
\end{tabular}

SIR standardized incidence ratios, MFs magnetic fields, HR hazard ratio, IRR incident rate ratios, SMRs standardized mortality ratios

were analyzed. Among the workers, who were never exposed to endotoxin, a comparison was made between lung cancer rates in workers hired more than 35 years before enrolment and workers hired less than or 35 years before enrolment. In the former group, a reduced risk (Incidence rate ratio, $I R R=0.74,95 \% \mathrm{CI}$ ) was found. An increased risk of lung cancer among workers hired for more than 50 years ago was also reported.

Dement and Brown [12] investigated the causes of deaths among textile workers and found 185 excess deaths $(S M R=1.44)$ out of a mortality of 1200 South Carolina textile workers. These excess deaths included 41 lung cancers $(\mathrm{SMR}=2.25), 43$ non-malignant respiratory diseases $(\mathrm{SMR}=2.25)$ and 71 cardiovascular diseases $(\mathrm{SMR}=1.37)$. In whole of the study, only two mesotheliomas cases were observed. Simpson et al. [45] examined the relation between women's health and their occupation. The study analyzed the data of
381,915 women cancer cases which were registered in England from 1971 to 1990, over the period of 20 -year. For exploring the value of the data, five sites (lung, pleura, bladder, breast and stomach) under two occupations including agriculture and textile were selected. The association between stomach cancer and "dusty" occupations were found to as PRR (Proportional registration ratios $)=198,95 \%(C I=126-298)$ for textile finishers. Similarly, Mastrangelo et al. [14] analyzed textile industry workers to evaluate the cancer risk within the textile industry in relation to the textile fibre being used or the specific type of job held in the industry. The decrease in the cases of upper respiratory tract cancer paralleled with a corresponding increase in the cases of lung cancer. Conclusively, the importance of preventive measures to reduce the lung cancer burden in the textile workers was emphasized. 


\section{Other cancer types}

Apart from occurrence of bladder and lung cancer cases in textile industry workers, various other cancer types are also reported in different studies. Camp et al. [15] assessed the development of a cancer study among Shanghai textile workers. The results of the study indicated that women employed in wool, cotton, mixed-fiber and machinemaintenance sectors have a significantly increased risk for breast cancer. De Roos et al. [17] investigated the probable risks of rectum and colon cancers in relation to different types of exposures in textile industry. The investigation revealed that certain long term exposures in textile industry may pose an increased risk of colorectal cancers. Hazard ratio for exposures especially to textile dyes and their intermediates with colon cancer was found to be $\mathrm{HR}=3.9$; 95 \% CI: 1.4-10.6 (> or $=20$ years exposure versus never). In the same way, Chang et al. [19] investigated the associations between biliary tract cancer (BTC) and occupational exposures to various chemicals and textile dusts in a cohort of 267,400 women textile workers. For employment in maintenance jobs, an increased risk of BTC was found $(\mathrm{HR}=2.92,95 \% \mathrm{CI}: 1.48,5.73)$ with a significant trend by duration of exposure. It was also suggested that long-term exposures to different metals and employment in maintenance sector in the textile industry may have played a role in elevating the BTC risks among textile industry workers. Fang et al. [46] investigated the cancer mortality in relation to cotton dust and endotoxin exposure in a cohort from Shanghai textile workers by assessing 444 cotton textile workers. A reference group of 467 persons who were unexposed silk workers was also recruited. Both the groups were followed for 30 years. Hazard ratios for all cancers (with and without lung cancer) and gastrointestinal cancer were estimated in Cox regression models. In comparison to silk workers, cotton workers were found to have increased risks of mortality from gastrointestinal cancers and all cancers combined [gastrointestinal cancer $\mathrm{HR}=4.1$ (1.8-9.7); all cancers $\mathrm{HR}=2.7$ (95 \% CI 1.4-5.2)]. A previous study by the present author also demonstrated genotoxic risk among textile industry workers [47].

\section{Conclusion}

Textile industry workers are exposed to a number of chemicals which are known to have carcinogenic properties. Reviewing the data of 54 research papers on textile industry workers revealed the occurrence of different types of cancers among them. Exposure to different sets of chemicals and physical factors in textile industry may induce occupational cancer as a long term effect among textile industry workers. Formulation and use of alternate non-toxic textile chemicals for different processes should be encouraged. Conclusively, proper protection equipments and other precautionary measures should be used by the workers while dealing with toxic chemicals in these industries.

\author{
Acknowledgements \\ Not applicable. \\ Funding \\ There is no funding source for the present study.
}

Availability of data and materials

Not applicable.

\section{Authors' contribution}

SZ conceived the study. CP participated in the design of the study. Both the authors drafted the manuscript. Both authors read and approved the final manuscript.

\section{Competing interest}

The authors declare that they have no competing interest.

Consent for publication

Not applicable.

Ethics approval and consent to participate

Not applicable.

\section{Financial support and sponsorship}

None.

\section{Author details}

${ }^{1}$ Department of Zoology, Khalsa College, G.T. Road, Amritsar, Punjab 143001, India. '2Department of Zoology, Guru Nanak Dev University, Amritsar, Punjab, India.

Received: 11 April 2016 Accepted: 8 August 2016

Published online: 15 August 2016

\section{References}

1. Moss E. Oral and pharyngeal cancer in textile workers. Ann N Y Acad Sci. 1976;271:301-7

2. Buiatti E, Baccetti S, Cecchi F, Tomassini A, Dolara P. Evidence of increased lung cancer rate among textile workers. Med Lav. 1979;70:21-3.

3. Heyden S, Pratt P. Exposure to cotton dust and respiratory disease. Textile workers, 'brown lung', and lung cancer. JAMA. 1980;244:1797-8.

4. Dement JM, Harris Jr RL, Symons MJ, Shy C. Estimates of dose-response for respiratory cancer among chrysotile asbestos textile workers. Ann Occup Hyg. 1982;26:869-87.

5. Delzell E, Grufferman S. Cancer and other causes of death among female textile workers, 1976-78. J Natl Cancer Inst. 1983;71:735-40.

6. Levin LI, Gao YT, Blot WJ, Zheng W, Fraumeni Jr JF. Decreased risk of lung cancer in the cotton textile industry of Shanghai. Cancer Res. 1987;47:5777-81.

7. O'Brien TR, Decoufle P. Cancer mortality among northern Georgia carpet and textile workers. Am J Ind Med. 1988;14:15-24.

8. Pearce N. Multistage modelling of lung cancer mortality in asbestos textile workers. Int J Epidemiol. 1988;17:747-52.

9. Sebastien P, McDonald JC, McDonald AD, Case B, Harley R. Respiratory cancer in chrysotile textile and mining industries: exposure inferences from lung analysis. Br J Ind Med. 1989;46:180-7.

10. Frumin $\mathrm{E}$, Velez $\mathrm{H}$, Bingham $\mathrm{E}$, Gillen $\mathrm{M}$, Brathwaite $\mathrm{M}$, LaBarck R. Occupational bladder cancer in textile dyeing and printing workers: six cases and their significance for screening programs. J Occup Med. 1990;32:887-90.

11. Zappa M, Paci E, Seniori CA, Kriebel D. Lung cancer among textile workers in the Prato area of Italy. Scand J Work Environ Health. 1993:19:16-20.

12. Dement JM, Brown DP. Lung cancer mortality among asbestos textile workers: a review and update. Ann Occup Hyg. 1994;38:525-32. 412

13. Serra $C$, Bonfill $X$, Sunyer J, Urrutia G, Turuguet $D$, Bastus $R$, Roque $M$, 't Mannetje A, Kogevinas M. Bladder cancer in the textile industry. Scand J Work Environ Health. 2000;26:476-81.

14. Mastrangelo G, Fedeli U, Fadda E, Milan G, Lange JH. Epidemiologic evidence of cancer risk in textile industry workers: a review and update. Toxicol Ind Health. 2002;18:171-81. 
15. Camp JE, Seixas NS, Wernli K, Fitzgibbons D, Astrakianakis G, Thomas DB, Gao DL, Checkoway H. Development of a cancer research study in the Shanghai textile industry. Int J Occup Environ Health. 2003;9:347-56

16. Lange JH, Mastrangelo G, Fedeli U, Rylander R, Christiani DC. A benefit of reducing lung cancer incidence in women occupationally exposed to cotton textile dust. Am J Ind Med. 2004;45:388-9.

17. De Roos AJ, Ray RM, Gao DL, Wernli KJ, Fitzgibbons ED, Ziding F, Astrakianakis G, Thomas DB, Checkoway H. Colorectal cancer incidence among female textile workers in Shanghai, China: a case-cohort analysis of occupational exposures. Cancer Causes Control. 2005;16:1177-88.

18. Pira E, Pelucchi C, Buffoni L, Palmas A, Turbiglio M, Negri E, Piolatto PG, La VC. Cancer mortality in a cohort of asbestos textile workers. Br J Cancer. 2005:92:580-6

19. Chang CK, Astrakianakis G, Thomas DB, Seixas NS, Camp JE, Ray RM, Gao DL, Wernli KJ, Li W, Fitzgibbons ED, Vaughan TL, Checkoway H. Risks of biliary tract cancer and occupational exposures among Shanghai women textile workers: a case-cohort study. Am J Ind Med. 2006:49:690-8.

20. Fang SC, Eisen EA, Dai H, Zhang H, Hang J, Wang X, Christiani DC. Cancer mortality among textile workers in Shanghai, China: a preliminary study. J Occup Environ Med. 2006:48:955-8.

21. Li W, Ray RM, Gao DL, Fitzgibbons ED, Seixas NS, Camp JE, Wernli KJ, Astrakianakis G, Feng Z, Thomas DB, Checkoway H. Occupational risk factors for pancreatic cancer among female textile workers in Shanghai, China. Occup Environ Med. 2006;63:788-93.

22. Tse LA, Yu IT. Re: 'Occupational exposures and risks of liver cancer among Shanghai female textile workers-a case-cohort study'. Int J Epidemiol. 2006;35:1359.

23. Astrakianakis G, Seixas NS, Ray R, Camp JE, Gao DL, Feng Z, Li W, Wernli KJ, Fitzgibbons ED, Thomas DB, Checkoway $H$. Lung cancer risk among female textile workers exposed to endotoxin. J Natl Cancer Inst. 2007;99:357-64.

24. Kuzmickiene I, Stukonis M. Lung cancer risk among textile workers in Lithuania. J Occup Med Toxicol. 2007;2:14.

25. Ray RM, Gao DL, Li W, Wernli KJ, Astrakianakis G, Seixas NS, Camp JE, Fitzgibbons ED, Feng Z, Thomas DB, Checkoway H. Occupational exposures and breast cancer among women textile workers in Shanghai. Epidemiology. 2007;18:383-92.

26. Reul NK, Li W, Gallagher LG, Ray RM, Romano ME, Gao D, Thomas DB, Vedal $\mathrm{S}$, Checkoway H. Risk ofPancreatic Cancer in Female Textile Workers in Shanghai, China, Exposed to Metals, Solvents, Chemicals, and Endotoxin: Follow-Up to a Nested Case-Cohort Study. J Occup Environ Med. 2016;58: 195-99.

27. Wernli KJ, Ray RM, Gao DL, Fitzgibbons ED, Camp JE, Astrakianakis G, Seixas N, Li W, De Roos AJ, Feng Z, Thomas DB, Checkoway H. Occupational risk factors for endometrial cancer among textile workers in Shanghai, China. Am J Ind Med. 2008;51:673-9.

28. Loomis D, Dement JM, Wolf SH, Richardson DB. Lung cancer mortality and fibre exposures among North Carolina asbestos textile workers. Occup Environ Med. 2009:66:535-42.

29. Lenters V, Basinas I, Beane-Freeman L, Boffetta P, Checkoway $H$, Coggon D, Portengen L, Sim M, Wouters IM, Heederik D, Vermeulen R. Endotoxin exposure and lung cancer risk: a systematic review and meta-analysis of the published literature on agriculture and cotton textile workers. Cancer Causes Control. 2010;21:523-55.

30. Checkoway H, Lundin Jl, Costello S, Ray R, Li W, Eisen EA, Astrakianakis G, Seixas N, Applebaum K, Gao DL, Thomas DB. Possible pro-carcinogenic association of endotoxin on lung cancer among Shanghai women textile workers. Br J Cancer. 2014;111:603-7.

31. Wang X, Lin S, Yano E, Yu IT, Courtice M, Lan Y, Christiani DC. Exposurespecific lung cancer risks in Chinese chrysotile textile workers and mining workers. Lung Cancer. 2014;85:119-24.

32. Kwon P, Lundin J, Li W, Ray R, Littell C, Gao D, Thomas DB, Checkoway $\mathrm{H}$. Night shift work and lung cancer risk among female textile workers in Shanghai, China. J Occup Environ Hyg. 2015;12:334-41.

33. Li W, Ray RM, Thomas DB, Davis S, Yost M, Breslow N, Gao DL, Fitzgibbons ED, Camp JE, Wong E, Wernli KJ, Checkoway H. Shift work and breast cancer among women textile workers in Shanghai, China. Cancer Causes Control. 2015:26:143-50.

34. Rylander R, Jacobs R. Comment on 'Possible pro-carcinogenic association of endotoxin on lung cancer among Shanghai women textile workers'. Br J Cancer. 2015;112:1840
35. Gonzales CA, Riboli E, Lopez-Abente G. Bladder cancer among workers in the textile industry: results of a Spanish case-control study. Am J Ind Med. 1988;14:673-80

36. Zheng W, McLaughlin JK, Gao YT, Silverman DT, Gao RN, Blot WJ. Bladder cancer and occupation in Shanghai, 1980-1984. Am J Ind Med. 1992;21:877-85.

37. Serra C, Kogevinas M, Silverman DT, Turuguet D, Tardon A, Garcia-Closas R, Carrato A, Castano-Vinyals G, Fernandez F, Stewart P, Benavides FG, Gonzalez S, Serra A, Rothman N, Malats N, Dosemeci M. Work in the textile industry in Spain and bladder cancer. Occup Environ Med. 2008;65:552-9.

38. Checkoway H, Ray RM, Lundin Jl, Astrakianakis G, Seixas NS, Camp JE, Wernli KJ Fitzgibbons ED, Li W, Feng Z, Gao DL, Thomas DB. Lung cancer and occupational exposures other than cotton dust and endotoxin among women textile workers in Shanghai, China. Occup Environ Med. 2011;68:425-9.

39. Agalliu I, Costello S, Applebaum KM, Ray RM, Astrakianakis G, Gao DL, Thomas DB, Checkoway $\mathrm{H}$, Eisen EA. Risk of lung cancer in relation to contiguous windows of endotoxin exposure among female textile workers in Shanghai. Cancer Causes Control. 2011;22:1397-404.

40. La VC, Boffetta P. Role of stopping exposure and recent exposure to asbestos in the risk of mesothelioma. Eur J Cancer Prev. 2012;21:227-30.

41. Elliott L, Loomis D, Dement J, Hein MJ, Richardson D, Stayner L. Lung cancer mortality in North Carolina and South Carolina chrysotile asbestos textile workers. Occup Environ Med. 2012;69:385-90.

42. Wang XR, Yu IT, Qiu H, Wang MZ, Lan YJ, Tse LY, Yano E, Christiani DC. Cancer mortality among Chinese chrysotile asbestos textile workers. Lung Cancer. 2012;75:151-5

43. Deng $Q$, Wang $X$, Wang $M$, Lan $Y$. Exposure-response relationship between chrysotile exposure and mortality from lung cancer and asbestosis. Occup Environ Med. 2012;69:81-6.

44. Applebaum KM, Ray RM, Astrakianakis G, Gao DL, Thomas DB, Christiani DC, LaValley MP, Li W, Checkoway H, Eisen EA. Evidence of a paradoxical relationship between endotoxin and lung cancer after accounting for left truncation in a study of Chinese female textile workers. Occup Environ Med. 2013;70:709-15.

45. Simpson J, Roman E, Law G, Pannett B. Women's occupation and cancer: preliminary analysis of cancer registrations in England and Wales, 19711990. Am J Ind Med. 1999:36:172-85.

46. Fang SC, Mehta AJ, Hang JQ, Eisen EA, Dai HL, Zhang HX, Su L, Christiani DC Cotton dust, endotoxin and cancer mortality among the Shanghai textile workers cohort: a 30-year analysis. Occup Environ Med. 2013;70:722-9.

47. Singh Z, Chadha P. Human health hazard posed by textile dyes: a genotoxic perspective. J Hum Health. 2015;1:42-5.

48. Li W, Ray RM, Thomas DB, Yost M, Davis S, Breslow N, Gao DL, Fitzgibbons ED, Camp JE, Wong E, Wernli KJ, Checkoway H. Occupational exposure to magnetic fields and breast cancer among women textile workers in Shanghai, China. Am J Epidemiol. 2013;178:1038-45.

49. Kuzmickiene I, Stukonis M. Cancer incidence among women flax textile manufacturing workers in Lithuania. Occup Environ Med. 2010;67:500-2.

50. Gunay E, Beser A. Sociodemographic characteristics of women who engage in early breast cancer diagnostic behaviors: the case of Turkish women working in a textile factory. AAOHN J. 2011;59:421-8.

51. Checkoway H, Lundin Jl, Costello S, Ray RM, Li W, Eisen EA, Astrakianakis G, Applebaum K, Gao DL, Thomas DB. Reply to comment on: 'Possible procarcinogenic association of endotoxin on lung cancer among shanghai women textile workers'. Br J Cancer. 2015;112:1840-1.

52. Gallagher LG, Rosenblatt KA, Ray RM, Li W, Gao DL, Applebaum KM, Checkoway $\mathrm{H}$, Thomas DB. Reproductive factors and risk of lung cancer in female textile workers in Shanghai, China. Cancer Causes Control. 2013;24:1305-14

53. Astrakianakis G, Seixas NS, Ray R, Camp JE, Gao DL, Feng Z, Li W, Wernli KJ, Fitzgibbons ED, Thomas DB, Checkoway H. Re: lung cancer risk among female textile workers exposed to endotoxin. J Natl Cancer Inst. 2010;102:913-4.

54. Loomis D, Dement JM, Elliott L, Richardson D, Kuempel ED, Stayner L. Increased lung cancer mortality among chrysotile asbestos textile workers is more strongly associated with exposure to long thin fibres. Occup Environ Med. 2012;69:564-8.

55. Wernli KJ, Ray RM, Gao DL, Fitzgibbons ED, Camp JE, Astrakianakis G, Seixas N, Wong EY, Li W, De Roos AJ, Feng Z, Thomas DB, Checkoway H. Occupational exposures and ovarian cancer in textile workers. Epidemiology. 2008;19:244-50. 